Journal Universitas Muhammadiyah Gresik Engineering, Social Science, and Health International Conference (UMGESHIC)

UMGCINMATIC : $1^{\text {st }}$ Rethinking Education during Covid-19 Era: Challange and Innovation

\title{
THE EFFECT OF "AKHLAK" ORGANIZATIONAL CULTURE ON EMPLOYEE PERFORMANCE WITH JOB SATISFACTION AS INTERVENING VARIABLE AT SEMEN GRESIK HOSPITAL
}

\author{
Author \\ Chairul Anam, Suyoto \\ Universitas Muhammadiyah Gresik \\ anamrssemengresik80@gmail.com
}

\begin{abstract}
This study aims to analyze how far the influence of Akhlak organizational culture which is the new organizational culture of BUMN on employee performance and job satisfaction levels at Semen Gresik Hospital. The data used were taken from organic employees of Semen Gresik Hospital as many as 101 people, with proportional sampling technique. Data collection by online questionnaire. Data processing using parth analysis of SPSS version 25 for windows. The results of the study found that Akhlak organizational culture variable had a direct and indirect effect on employee performance and job satisfaction. The direct influence of Akhlak organizational culture on employee performance is 0.357 smaller than the indirect influence of Akhlak organizational culture on employee performance through job satisfaction as an intervening variable of 0.434 .
\end{abstract}

Keywords - Akhlak Organizational Culture, Employee Performance, Job Satisfaction 


\section{INTRODUCTION}

Globalization is a global giant capitalist process of doing business throughout the world without any barriers (no entry barriers), therefore all companies, both service and goods companies, must have anticipatory strategies in winning the competition or staying afloat. One of the anticipatory measures is to strengthen human resources (HR), with reliable HR management, both planning, organizing, actuating, and controlling (POAC) to achieve the company's goals and ideals. The hospital is one of the companies engaged in health services to the community. In the era of disruption 4.0 which was implemented in various industries, hospitals which were included in the health service industry did not escape these changes.

Semen Gresik Hospital has implemented a 4.0 digitization-based program in several services such as online doctor consultation (telemedicine), registration for doctor examinations with the online WhatsApp application, drug delivery services to patients' homes and many other services. To carry out these services, of course, requires competent human resources in order to produce high employee performance. Based on employee performance appraisal in semester 1 of 2020 , employee performance is around $72 \%$ (80\% company KPI standard), the decline in employee performance can be seen from the increasing number of incoming criticisms \& suggestions, in 2020 there were 80 criticisms, an increase from the previous year, and occurred in patient care unit from registration to pharmacy services.

Employee performance is a set of results achieved and refers to the act of achieving an assigned job (Indrasari, 2017). One of the efforts to improve employee performance is by creating a work culture or organizational culture. Organizational culture is actually a set of assumptions or beliefs, values and norms developed within the organization that can be used as a reference in overcoming problems of external and internal adaptation (Mangkunegara, 2017).

Rumah Sakit Semen Gresik mengenal budaya organisasi perusahaan sejak tahun 2017, dengan nama budaya organisasi "SPIRIT" (Safety, Profesional, Integrity, Reliable, Innovative dan Teamwork). Akan tetapi budaya organisasi tersebut belum sepenuhnya menjiwai sebagai budaya organisasi serta belum memberikan konstribusi yang nyata bagi peningkatan kinerja karyawan. Sebagai contoh dibeberapa kegiatan masih didapatkan karyawan lebih mengedepankan kepentingan pribadi atau unit kerja mereka dibandingkan kepentingan perusahaan. Pertengahan tahun 2020 RS Semen Gresik bergabung dalam induk organisasi kesehatan BUMN atau IHC (Indonesia Healthcare Corporation) yang dicanangkan Menteri BUMN melalui Surat Edaran Nomor SE-7/MBU/07/2020 tanggal 1 Juli 2020 tentang tata nilai baru sumber transformasi berupa budaya organisasi "Akhlak", kepanjangan dari Amanah, Kompeten, Harmonis, Loyal, Adaptif, Kolaboratif. Budaya organisasi ini diharapkan mampu menjawab tantangan bisnis yang terjadi, dapat meningkatkan kinerja karyawan yang nantinya berdampak pada peningkatan kinerja perusahaan dan organisasi.

Semen Gresik Hospital has recognized the company's organizational culture since 2017, with the name "SPIRIT" organizational culture (Safety, Professional, Integrity, Reliable, Innovative and Teamwork). However, the organizational culture has not yet fully imbued itself as an organizational culture and has not made a real contribution to improving employee performance. For example, in some activities, it is still found that employees prioritize their personal or work unit interests over the interests of the company. In mid-2020, Semen Gresik Hospital joined the parent health organization of BUMN or IHC (Indonesia Healthcare Corporation) which was launched by the Minister with SE No : 7/MBU/07/2020 dated July 1, 2020 regarding the new 
values for the source of transformation in the form of "Akhlak" organizational culture, stands for Amanah, Competent, Harmonious, Loyal, Adaptive, Collaborative. This organizational culture is expected to be able to answer business challenges that occur, can improve employee performance which will have an impact on improving company and organizational performance.

The Akhlak organizational culture is slightly different from the organizational culture that has existed previously where the first component is Amanah, with a very deep meaning content, related to beliefs or religious elements, that work is not solely for making money, our work in the world will be judged in the world. another life (hereafter). For the second component, namely Competence, it means being qualified in terms of knowledge, attitude and skills and having a high willingness to learn new things according to the company's development. The third component is harmony, emphasizing mutual respect for everyone indiscriminately. The fourth component is loyalty or loyalty which means being obedient to the leadership, being able to maintain the good name of the company and the nation and state, here the emphasis is on working and sacrificing for the common interest, the interests of the company or nation and state above personal interests, work units or groups. The next component is adaptive, which means full of innovation and enthusiasm in dealing with changes that occur, easy to adapt, always proactive and not passive to challenges and changes in the company's business. The last component is collaborative or able to work together synergistically between employees, work units, companies by utilizing existing resources.

From the results of measuring the level of employee performance between the old organizational culture and Akhlak organizational culture, it was found that there was an increase in performance but it was not significant, it could be because the application of Akhlak organizational culture was still running recently. This confirms the research of Nurhalim \& Sudarsih (2015) that the application of organizational culture has a positive but not significant effect on employee performance at the Jember Branch of Bank Indonesia. In contrast to the two researchers above, Thohir \& Agustian (2020) say that one of the efforts that can be used to improve employee performance is to create a shared view of organizational culture. This opinion is supported by the research journal Ekpenyoung, N \& Ekpenyoung, A (2016) that organizational culture affects employee performance, increasing and decreasing employee performance depends on the organizational culture. From the differences between the two journals and the opinions above, it raises interest in further research on the influence of organizational culture on employee performance.

Improved performance is needed in the Covid-19 pandemic, where the room occupancy rate or BOR (Bed Occupancy Ratio) has decreased significantly, due to public fear of using existing health services, including hospital health services. According to Fahmi (2018), many changes that occur in the business environment are caused by external factors that are uncontrollable, so that it is necessary to continuously improve optimal employee performance in facing all challenges that occur both internally and externally.

At Semen Gresik Hospital, in carrying out efficiency during the pandemic, several policies have been carried out, namely suppressing and eliminating overtime hours, delaying the acceptance of new employees to replace employees who are retired, while the duties of employees who are retired are assigned to existing employees. This policy creates feelings of dissatisfaction among employees where employees are required to work more without being compensated in the form of additional income. The compensation is only given to certain work units or rooms that treat Covid-19 patients. According to Sinambela (2012), employee job satisfaction is closely related to employee performance, where job satisfaction is maintained, employees will try to improve their performance, because employees get justice and make employee psychological agreements with the company.

Based on data regarding the level of employee satisfaction in the last year showing a decline, 
in 2020 it decreased by $3 \%$, the exact cause is not yet known, it could be due to the impact of the implementation of company policies by making labor cost efficiency, especially during the covid19 pandemic or other reasons. In the research journal Wijaya (2018), it is stated that job satisfaction has a positive effect on employee performance, where companies if they wish to improve their employee performance, the level of job satisfaction of employees must be increased first, agreeing with Damayanti, et al (2018), concluding that there is a strong and significant relationship between job satisfaction and employee performance. According to Indrasari (2017) job satisfaction and performance are largely determined by the comparison between what the job gives them and what they give to the job. In contrast to some of the journals above, the Dasaad research journal (2015) argues that job satisfaction has nothing to do with employee performance and employee performance is influenced by external factors, including leadership.

Based on all the problems above, it is interesting to conduct research on the influence of Akhlak organizational culture on employee performance at Semen Gresik Hospital with employee satisfaction as an intervening variable, where Akhlak organizational culture is a new organizational culture and at this time there is no research on this Akhlak culture. The formulation of the problem to be analyzed is:

1. Is there any influence between Akhlak organizational culture and employee job satisfaction?

2. Is there an influence between job satisfaction and employee performance?

3. Is there any influence between Akhlak organizational culture and employee performance?

4. Is there any influence between Akhlak organizational culture and employee performance through job satisfaction as a mediation?

\section{METHODS}

\section{Data Analysis Techniques}

The data analysis method used is a quantitative analysis method, using the SPSS.25 program.

\section{Validity Test}

The validity test is used to measure the validity of a questionnaire that has been distributed by the researcher, by comparing the $r$ count (correlated item-total correlation) with the $r$ table value. If the value of $r$ count $>r$ table and the value is positive, then the statement is said to be valid, if $r$ arithmetic $<\mathrm{r}$ table, then it is said to be invalid.

\section{Reliability Test}

This is done by looking at the Cronbach's Alpha value, if the Cronbach's Alpha value $>0.70$ is said to be reliable, otherwise if the Cronbach's Alpha value < 0.70 is unreliable (Ghozali, 2016). Before the questionnaires were distributed to respondents, a trial was conducted with 30 respondents.

\section{Test-Assumption-Classic}

a. Normality test

To test whether in the regression model there is a confounding variable or not, it is said to be normal if the data distribution is normally distributed or can be seen by looking at the line plot that describes the data that follows the normal line.

\section{b. Multicollinearity Test}

The main purpose of multicollinearity testing is to test the data in this study whether the regression model used has a correlation between the independent variables, including by looking at the VIF (Variance Inflation Factor) value.

\section{c. Heteroscedasticity Test}

In heteroscedasticity testing to test whether the data in the regression model has inequality between 
residual variances from one observation to another (Ghozali, 2016).

\section{d. Linearity Test}

The linearity test aims to determine whether the linear relationship between the independent variable and the dependent variable is correct or not (Ghozali, 2016).

\section{Path analysis}

To analyze the direct and indirect effects through the mediating variable (intervening). then to Test the Detection of Mediation Effects with the Sobel Test.

\section{Direct Effect Hypothesis Testing}

The t-test serves to determine whether the independent variable partially has a positive or negative influence on the dependent variable with the probability of obtaining a significant or non-significant opportunity. As a basis for making decisions by comparing the value of $t$ count with $t$ table:

- If $\mathrm{t}$ count $\mathrm{t}$ table, Ho is accepted and $\mathrm{H} 1$ is rejected, it means that it is not significant

- If $\mathrm{t}$ count $\mathrm{t}$ table, Ho is rejected and $\mathrm{H} 1$ is accepted, it means significant (with significance level: 0.05

\section{RESULTS AND DISCUSSION}

\section{Respondent Identity}

The respondents of this study were all permanent employees of Semen Gresik Hospital who were willing to be the research sample and met the health requirements, amounting to 101 of 142 people using a questionnaire. The description of the research respondents is as follows:

\section{a. Respondent's age}

\section{Respondent Age Table}

\begin{tabular}{|c|c|c|}
\hline Age range (years) & Amount & Percentage (\%) \\
\hline $38-40$ & 12 & $11,9 \%$ \\
\hline $41-43$ & 17 & $16,8 \%$ \\
\hline $44-46$ & 26 & $25,8 \%$ \\
\hline $47-49$ & 13 & $12,8 \%$ \\
\hline $50-52$ & 19 & $18,9 \%$ \\
\hline $53-55$ & 14 & $13,8 \%$ \\
\hline Amount & 101 & $100 \%$ \\
\hline
\end{tabular}

Source: Processed primary data, 2021

Based on the age table, the majority of respondents aged $44-46$ years as much as $25.8 \%$, this shows that the selected respondents are in late adulthood where the way of thinking or opinion already has adequate maturity.

\section{b. Respondent's Gender}

\begin{tabular}{|c|c|c|}
\hline Gender & Amount & Percentage (\%) \\
\hline Man & 38 & $37,6 \%$ \\
\hline Female & 63 & $62,4 \%$ \\
\hline Amount & 101 & $100 \%$ \\
\hline
\end{tabular}

Source: Processed primary data, 2021

Based on the gender table, the majority of respondents are women as much as $62.4 \%$. This shows that the female sex dominates because it can be accepted in all work units, especially patient care.

\section{c. Respondent Education Level}

Table Education Level

\begin{tabular}{|c|c|c|}
\hline Education Level & Amount & Percentage (\%) \\
\hline SMP & 0 & $0 \%$ \\
\hline
\end{tabular}


UMGCINMATIC : $1^{\text {st }}$ Rethinking Education during Covid-19 Era: Challange and Innovation Volume 1 No 2

\begin{tabular}{|c|c|c|}
\hline SMA & 12 & $11,9 \%$ \\
\hline D3 & 56 & $55,4 \%$ \\
\hline S1/S2 & 33 & $32,7 \%$ \\
\hline Amount & 101 & $100 \%$ \\
\hline
\end{tabular}

Source: Processed primary data, 2021

Based on the education level of the most respondents is D3 55.4\%, this shows that the hospital staff, both paramedics and medical support, are in accordance with their level of education and competence with hospital accreditation standards.

\section{d. Respondent's work unit}

Table Work unit

\begin{tabular}{|c|c|c|}
\hline Work unit & Amount & Percentage (\%) \\
\hline Nursing & 44 & $43,6 \%$ \\
\hline Medical Services & 8 & $7,9 \%$ \\
\hline Medical support & 13 & $12,9 \%$ \\
\hline Pharmacy & 8 & $7,9 \%$ \\
\hline Logistic & 7 & $6,9 \%$ \\
\hline Finance & 16 & $15,9 \%$ \\
\hline General & 5 & $4,9 \%$ \\
\hline Amount & 101 & $100 \%$ \\
\hline
\end{tabular}

Source: Processed primary data, 2021

Based on the work unit table, the majority of respondents were nursing $43.6 \%$. This shows that operational staff who work 24 hours in providing nursing care to patients are nursing.

\section{Data Analysis}

\section{a. Instrument Test}

The research instrument test, namely the Validity test and Reliability test with the SPSS 25 program, obtained valid and reliable instrument results with Cronbach's Alpha value $>0.70$.

\section{b. Classic assumption test}

Classical assumption test with normality test, multicollinearity test, heteroscedasticity test and linearity test the results obtained according to the standard set.

\section{c. Path Analisys}

1) The direct influence of the Akhlak organizational culture variable $(X)$ on job satisfaction $(Z)$ is $=0.754$, the direct influence of the job satisfaction variable $(Z)$ on employee performance

$(\mathrm{Y})$ is 0.576 and the direct influence of the Akhlak organizational culture variable $(\mathrm{X})$ on performance Employees (Y) of $\mathbf{0 . 3 5 7}$

2) The indirect effect of the Akhlak organizational culture variable (X) on employee performance (Y) through job satisfaction $(\mathrm{Z})$ is $(0.754 \times 0.576)=0.434$

Based on the results of the path analysis above, the indirect effect is greater than the direct effect. Furthermore, the Detection Test for Mediation Effects was carried out with the Sobel Test. Sobel Test was found to have a significance value of $<0.05$, which means that the job satisfaction variable can mediate the relationship between Akhlak organizational culture variables and employee performance.

\section{CONCLUSIONS AND RECOMMENDATIONS}

\section{Conclusions}

Based on the results of the study, it can be concluded that: 
1) The results of testing the research hypothesis show that Akhlak organizational culture has a direct effect on job satisfaction.

2) The results of testing the research hypothesis show that job satisfaction has a direct effect on employee performance.

3) The results of testing the research hypothesis show that Akhlak organizational culture has a direct effect on employee performance

4) The results of testing the research hypothesis show that Akhlak organizational culture has an indirect effect on employee performance through job satisfaction, where the indirect effect is greater than the direct effect.

\section{Recommendations}

Recommendations that can be given are as follows:

1. Recommendations to the management of Semen Gresik Hospital, where Akhlak organizational culture has a real influence on employee performance both directly and indirectly through job satisfaction as a mediation. Based on the results of the analysis so that the implementation of Akhlak culture is even better, it is necessary to increase the moral component, namely Amanah (commitment to the company and adhering to morals and ethics) by conducting socializations or sharing knowledge in work units at Semen Gresik Hospital, so that moral culture is more embedded in organizational life in supporting the progress of the company and improving employee performance. In this study also found that employee performance will increase even more if employee job satisfaction also increases, by creating a good relationship between management and employees.

2. This research only discusses the application of Akhlak organizational culture to employee performance with employee satisfaction as an intervening variable at Semen Gresik Hospital, for further research recommendations if using a Akhlak organizational culture can use this research as literacy, while for other organizational cultures it is not investigated

\section{References}

Abdul Rahman, Agus, (2016) Metode Penelitian Psikologi Langkah Cerdas Menyelesaikan Skripsi, Bandung : PT Remaja Rosdakarya.

Agus A, Lutfiah., Budi Nurrharjo \& M. Syaharudin. (2016). Pengaruh Budaya Organisasi Dan Motivasi terhadap Kinerja Karyawan pada Rumah Sakit Wijaya Kusuma Kabupaten Lumajang. Artikel Ilmiah Mahasiswa .

Alamsyah, Muazzan., \& Andri Seno. (2016). Pengaruh Perkembangan Karir dan Komitmen Organisasi terhadap Kinerja Karyawan pada PT Indah Logistik Cargo Pekan Baru. Jurnal Jom FISIP.

Ali, K., \& Agustian, D. W. (2018). Pengaruh Budaya Organisasi Dan Gaya Kepemimpinan terhadap Kepuasan Kerja (Studi Di Rumah Sakit Muhammadiyah Metro). Jurnal Manajemen Magister.

Arikunto, Suharsimi (2019). Prosedur Penelitian. Jakarta: Rineka Cipta.

Damayanti, Riski., Agustina Hanafi., \& Afriyadi Cahyadi (2018). Pengaruh Kepuasan Kerja terhadap Kinerja Karyawan Rumah Sakit Islam Siti Khotidjah Palembang. Jurnal Ilmiah Manajemen Bisnis dan Terapan, Tahun XV No.2 .

Dasaad (2015). Analisis Hubungan Kepemimpinan dan Kepuasan Kerja terhadap Kinerja Karyawan pada PT Adam Jaya. Jurnal Ekonomi Bisnis Vol 20.

Effendi, A. (2016). The Power of Good Corporate Governance Teori dan Implikasi. Jakarta: Salemba Empat. 
Ekpenyoung Nkereuwem, S., \& Ekpenyoung Alfred, S. (2016). Organizational Culture and Its Impact on Employee Performance and Job Satisfaction: A Case Study of Niger Delta University, Amassoma. Higher Education of Social Science.

Fahmi, Irham (2018). Pengantar ilmu kepemimpinan. Depok ; Rajawali Pers

Ghozali, Imam. (2016). Aplikasi Analisis Multivariete Dengan Program IMB SPSS 23, Semarang: Badan Penerbit Universitas Diponegoro.

Hafid, H. (2018). Pengaruh Kompetensi, Kepemimpinan Dan Disiplin Kerja Terhadap Kinerja Pegawai Pada Samsat Polewali Mandar. Development Research of Management: Jurnal Manajemen.

Hasibuan, M.S.P. (2016). Manajemen Sumber Daya Manusia. Edisi Revisi Jakarta: Bumi Aksara. Herawan, Koko., M. Djudi Mukzam., \& Gunawan, E, N (2015). Pengaruh Budaya Organisasi Terhadap Kepuasan Kerja Studi Pada Bank Rakyat Indonesia Persero Kantor Cabang Kota Malang Kawi. Jurnal Administrasi Bisnis Vol 1.

Hurriyati (2010). Bauran Pemasaran dan Loyalitas Konsumen. Bandung: Alphabetha.

Meithiana Indrasari (2017). Kepuasan kerja dan kinerja karyawan : tinjauan dari dimensi iklim organisasi, kreativitas individu, dan karakteristik pekerjaan.. Sidoarjo : Indomedia Pustaka,.

Isa, M. F. M., Ugheoke, S. O., \& Noor, W. S. W. M. (2016). The Influence of Organizational Culture on Employees' Performance: Evidence from Oman. Journal of Entrepreneurship and Business.

Isvandiari, A. N. Y., Dpk, D., Manajemen, J., \& Asia, S. (2017). Pengaruh Budaya Organisasi, Disiplin Kerja, dan Kepuasan Kerja Terhadap Kinerja Karyawan Non Medis Rumah Sakit Islam Malang. JIBEKA.

Mangkunegara, A,A. Anwar Prabu (2017). Perilaku Organisasi dan Budaya Organisasi. Edisi 4. Bandung: PT Refika Aditama.

Mariati \& Hanif Mahmudin (2018). The Influence of Organizational culture and work Motivation on Employee Performance, Job Satisfaction As Intervening Variable ( Study On Secretariat Staff of Pasuruan Regency). Journal of Business and Management IOSR.

Marwansyah (penulis). (2019). Manajemen sumber daya manusia. Bandung : Alfabeta, Muhammad, Abdullah Bin. (2012). Kemudahan dari Allah: ringkasan tafsir ibnu katsir. Depok: Gema Insani,.

Mustafid, M. (2017). Pengaruh Budaya Organisasi terhadap Kepuasan Kerja Karyawan Pada PT LKis Pelangi. Universitas Sunan Kalijaga Yogyakarta.

Nisa, D. K., Santoso, B., \& Azhad, M. N. (2018). Pengaruh Budaya Organisasi dan Organizational Citizenship Behavior (OCB) terhadap Kinerja Pegawai Rumah Sakit Tk. III Baladhika Husada Jember. International Journal of SocialScienceandBusines.

Notoatmodjo, Soekidjo. (2015). Pendidikan dan perilaku kesehatan. Jakarta : Rineka Cipta,

Novziransyah, N. (2017). Pengaruh Budaya organisasi terhadap Kinerja Karyawan PT. PLN (PERSERO) Kantor Wilayah Sumatera Utara Medan. Jurnal JUMANTIK.

Nurhalim, F., Tobing, D. S. K., \& Sudarsih. (2015). Pengaruh Budaya Organisasi, Lingkungan Kerja dan Organizational Citizenship Behavior Terhadap Kinerja Karyawan Bank Indonesia Cabang Jember. Jurnal Artikel Ilmiah Mahasiswa.

Nursalam. (2017). Metode Penelitian Ilmu Keperawatan: Pendekatan Praktis. Jakarta : Salemba Medika,

Pasinringi, S. A., \& Bahar, B. (2018). Pengaruh budaya organisasi terhadap Kinerja Instalasi Rawat Inap rumah sakit Umum Daerah Kabupaten Kotabaru Kalimantan Selatan. Jurnal Universitas Hasanudin Makasar 
Peruri. (2020). Buku Panduan Perilaku Akhlak. Jakarta: Peruri

Primasheila, Debitri., Agustina Hanafi., \& Supardi A. Bakri. (2017). Pengaruh budaya organisasi terhadap Kepuasan Kerja Karyawan PT Telkom Kantor Wilayah Palembang. Jurnal Ilmiah Manajemen Bisnis dan Terapan, Tahun XIV No.1 .

Priyono. (2016). Manajemen Sumber Daya Manusia. Edisi 3. Sidoarjo: Zifatama Publisher. Rahman, Abdul (2016). Metode Penelitian Psikologi Langkah Cerdas Menyelesaikan Skripsi. Bandung: Remaja Rosdakarya

Rezanto, Abie (2020). Pengaruh Budaya Organisasi Terhadap Kinerja Karyawan Dengan Kepuasan Kerja Sebagai Variabel Mediasi Pada PT PJB Kantor Pusat . Perpustakaan Universitas Airlangga.

Rivai, Abdul \& Darsono P, N,. (2015). Manajemen Strategis. Jakarta: Mitra Wacana Media. Rukmawati. (2016). Pengaruh Budaya Organisasi dan Gaya Kepemimpinan terhadap Kinerja Pegawai (Study Kasus di Balai Pelatihan Peternakan Kupang). Jurnal Manajemen Dan Bisnis.

Siagian, Sondang (2012). Manajemen Sumber Daya Manusia. Jakarta: Bumi Aksara.

Sinambela, Lijan Poltak. (2012). Kinerja pegawai : teori pengukuran dan implikasi. Yogyakarta : Graha Ilmu

Singgih Santoso. (2014). Statistik non parametrik : konsep dan aplikasi dengan SPSS. Jakarta : Elex Media Komputndo,.

Siregar, Meysa (2018). Rahasia Harmonis . Jakarta : Okeyzone.

Soekidjo Notoatmodjo. (2015). Pendidikan dan perilaku kesehatan. Jakarta : Rineka Cipta, Sugiyono. (2016.). Metode Penelitian kuantitatif, kualitatif dan R \& D. Bandung : Alfabeta,. Syamsudin, Hasyim. (2015). Akhlak Tasawuf. Purwokerto: Madani .

Syukrina, A., Kartikowati, S., \& Setiawan, D. (2019). Pengaruh Budaya Organisasi dan Kepuasan Kerja Terhadap Motivasi dan Kinerja Perawat Tetap pada RSUD Arifin Achmad Riau. Jurnal Ilmiah Manajemen.

Thamrin, MH.(2015). Perencanaan manajemen sumber daya manusia. Yogyakarta: Deepublish,. Thohir, Erick \& Agustian, Ary Ginanjar. 2020. Akhlak Untuk Negeri. Edisi 1. Jakarta: PT Arga Tilanta.

Tun Huseno. (2016). Kinerja pegawai: tinjauan dan dimensi kepemimpinan, misi organisasi, budaya dan kepuasan kerja. Malang: Media Nusa Creative.

Widodo \& Suparno. (2015). Manajemen Pengembangan Sumber Daya Manusia.Yogyakarta: Pustaka Pelajar.

Wijaya, Iwan Kurnia (2018). Pengaruh Kepuasan Kerja Kinerja Karyawan CV Bukit Sanomas. Jurnal Agora.

Wiratna, Sujarweni (2015.). Metode Penelitian Bisnis dan Ekonomi. Yogyakarta : Pustaka Baru Press.

Zulkifli Rusby. (2017). Manajemen sumber daya manusia. Depok : Raja Grafindo Persada, 